\title{
Implementasi Metode Klasifikasi Multilabel Untuk Kategorisasi Materi Pembelajaran Secara Otomatis
}

\author{
Fadilla Sukma Alfiani*1, Umi Laili Yuhana² \\ ${ }^{1,2}$ Departemen Teknik Informatika, Institut Teknologi Sepuluh Nopember, Surabaya, Indonesia \\ e-mail: *11 fadilla16@mhs.if.its.ac.id, ${ }^{2}$ yuhana@if.its.ac.id
}

\begin{abstract}
Abstrak
Pembelajaran adaptif merupakan pembelajaran yang mampu menyesuaikan materi pembelajaran berdasarkan kemampuan siswa. Untuk memudahkan pemilihan materi pembelajaran yang sesuai, perlu dilakukan kategorisasi materi pembelajaran terlebih dahulu. Materi pembelajaran banyak tersedia secara daring dan dapat diakses dengan mudah melalui internet. Materi pembelajaran dapat dikategorisasikan menjadi beberapa topik dan subtopik. Penelitian ini bertujuan untuk membangun sebuah sistem yang dapat mengambil materi pembelajaran dari situs web dan mengkategorisasikan materi pembelajaran tersebut secara otomatis berdasarkan topik dan subtopiknya menggunakan klasifikasi multilabel. Dari eksperimen yang telah dilakukan, implementasi klasifikasi multilabel berhasil digunakan untuk melakukan kategorisasi materi pembelajaran secara otomatis berdasarkan topik dan subtopik pembelajaran.
\end{abstract}

Kata kunci-klasifikasi multilabel, materi pembelajaran, kategorisasi otomatis, pemrosesan teks

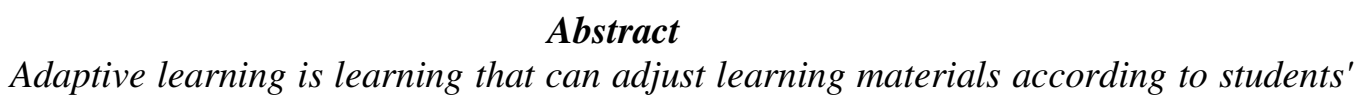
abilities. To facilitate the selection of appropriate learning materials, it is necessary to categorize learning materials first. Learning materials are widely available online and can be accessed easily via internet. Learning materials can be categorized into several topics and subtopics. This study aims to build a system that can retrieve learning materials from websites and categorize learning materials automatically based on topics and subtopics using multilabel classification. From the experiments that have been carried out, the implementation of multilabel classification has been successfully used to categorize learning materials automatically based on learning topics and subtopics.

Keywords - multilabel classification, learning material, automatic categorization, text processing

\section{PENDAHULUAN}

Perkembangan terkini di bidang teknologi komputer dan kecerdasan artifisial mampu menciptakan kemajuan di berbagai bidang, salah satunya di bidang pendidikan. Sebuah konsep baru yang disebut pembelajaran adaptif muncul sebagai contoh kemajuan teknologi informasi dan komunikasi dalam domain pendidikan. Pembelajaran adaptif merupakan pembelajaran yang dapat dikustomisasi sesuai dengan kebutuhan seorang individu sehingga tidak ada generalisasi pengguna. Pembelajaran adaptif bertujuan untuk menyediakan pembelajaran yang efisien dan efektif bagi setiap siswa [1]. Sistem pembelajaran adaptif mampu menyesuaikan konten atau materi pembelajaran berdasarkan kemampuan individual siswa [2]. 
Salah satu tantangan dalam sistem pembelajaran adaptif adalah pemilihan materi pembelajaran yang sesuai dengan kemampuan siswa. Untuk memudahkan hal tersebut, perlu dilakukan kategorisasi materi pembelajaran berdasarkan topik atau kompetensi terlebih dahulu. Namun dengan banyaknya materi pembelajaran yang tersedia, kategorisasi materi pembelajaran dilakukan secara manual tentu akan akan sangat melelahkan dan memakan banyak waktu sehingga tidak efisien. Oleh karena itu, kategorisasi materi pembelajaran seharusnya dilakukan dengan menerapkan klasifikasi secara otomatis.

Penelitian tentang klasifikasi teks sudah banyak dilakukan. Namun, penelitian yang berfokus pada klasifikasi konten atau materi pembelajaran tidak banyak ditemui. Salah satu penelitian tentang klasifikasi materi pembelajaran adalah klasifikasi sumber belajar berbasis teks pada mata pelajaran di Sekolah Menengah Kejuruan (SMK) rumpun Teknologi Informasi dan Komunikasi (TIK) [3]. Sumber belajar yang digunakan merupakan dokumen atau artikel yang diperoleh dari beberapa situs yang berisi materi-materi pelajaran. Sumber belajar tersebut dikelompokkan berdasarkan kriteria atau ciri esensial setiap mata pelajaran.

Penelitian lain terkait klasifikasi konten pembelajaran dilakukan oleh Gunarathne et. al. dengan mengusulkan klasifikasi konten pembelajaran secara otomatis untuk repositori Open Educational Resource (OER) [4]. Dengan penelitian ini diharapkan penyedia materi tidak perlu memilih kategori materi secara manual ketika menambahkan materi ke repositori. Sistem secara otomatis akan menampilkan daftar kategori yang relevan untuk materi yang akan ditambahkan.

Sementara itu, Lalitha \& Sreeja mengusulkan pembuatan sistem pembelajaran adaptif dengan salah satu modul utamanya adalah modul klasifikasi [5]. Modul klasifikasi penting diimplementasikan untuk melakukan kategorisasi konten atau materi pembelajaran yang tersedia bebas di internet. Penelitian ini menyebutkan bahwa dalam modul klasifikasi dilakukan praproses konten dan implementasi algoritma klasifikasi. Dari beberapa hasil studi literatur di atas, dapat disimpulkan bahwa klasifikasi materi pembelajaran berdasarkan topiknya merupakan salah satu proses penting dalam domain pembelajaran.

Seiring dengan pesatnya kemajuan teknologi di era ini, banyak materi pembelajaran yang tersedia secara daring dan dapat diakses dengan mudah menggunakan internet. Materi pembelajaran berkualitas yang tersedia di internet dapat dijadikan sebagai sumber belajar utama bagi siswa [6]. Materi pembelajaran dapat dikategorikan berdasarkan topik dan subtopik. Materi pembelajaran juga dapat memiliki lebih dari satu topik atau subtopik yang berbeda. Misalnya, materi pembelajaran tentang sistem pencernaan manusia dapat dikategorikan ke dalam subtopik organ pencernaan, proses pencernaan, dan gangguan pencernaan.

Berdasarkan latar belakang tersebut, maka penelitian ini bertujuan untuk membangun sebuah sistem yang dapat mengambil materi pembelajaran dari situs web dan mengkategorisasikan materi pembelajaran tersebut secara otomatis berdasarkan topik dan subtopik pembelajaran menggunakan klasifikasi multilabel.

\section{METODOLOGI}

Diagram alir pengembangan sistem kategorisasi materi pembelajaran secara otomatis ditunjukkan oleh Gambar 1. Terdapat empat tahapan utama yang akan dijelaskan masingmasing pada subbab berikut. 


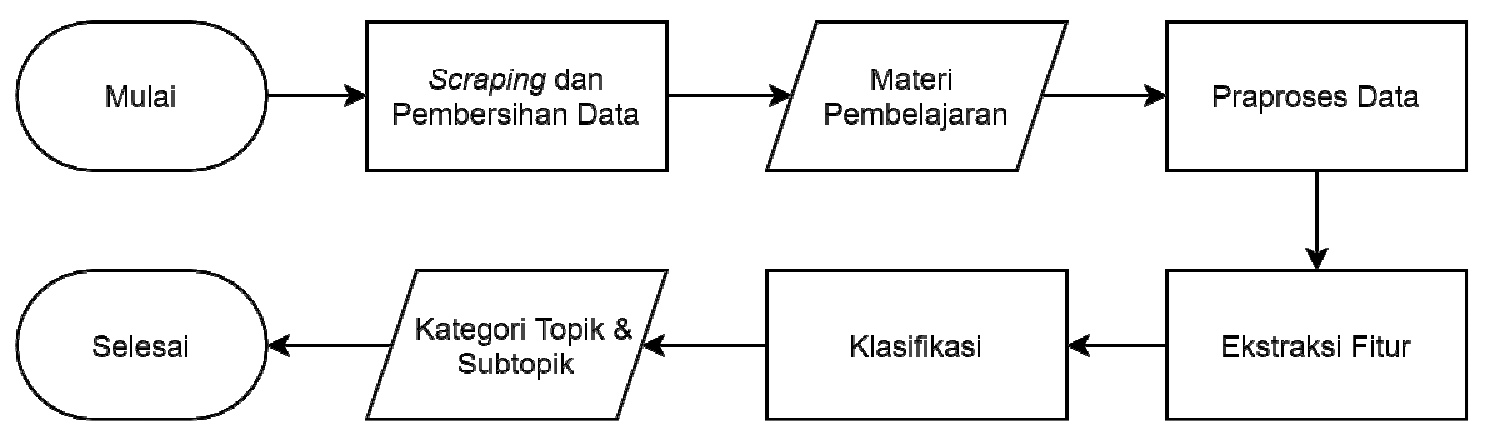

Gambar 1. Diagram Alir Sistem

\subsection{Scraping dan Pembersihan Data}

Scraping dilakukan untuk mengambil konten dari sebuah situs atau laman web. Sedangkan proses pembersihan data dilakukan untuk menghapus tag-tag yang tidak diperlukan terhadap hasil scraping yang telah didapatkan sebelumnya. Proses scraping dan pembersihan data diimplementasikan dengan menggunakan bantuan pustaka yang ada pada bahasa pemrograman Python. Tahapan proses scraping dan pembersihan data ditunjukkan pada Gambar 2. Langkah pertama yang perlu dilakukan adalah menentukan URL situs web yang memuat materi pembelajaran. Konten pada situs web tersebut akan diambil untuk nantinya diproses dalam tahap klasifikasi. Untuk membuka dan membaca URL dari sebuah situs digunakan pustaka Urllib. Hasil keluarannya berupa konten web dalam bentuk teks. Konten tersebut mengandung banyak tag HTML maupun CSS atau Javascript code yang tidak berperan penting dalam proses klasifikasi. Oleh karena itu, perlu dilakukan pembersihan teks dengan menghapus tag dan code yang tidak berguna. Proses ini diimplementasikan dengan menggunakan library BeautifulSoup. Dari tahap scraping dan pembersihan data ini diperoleh konten web yang sudah bersih berupa teks materi pembelajaran.

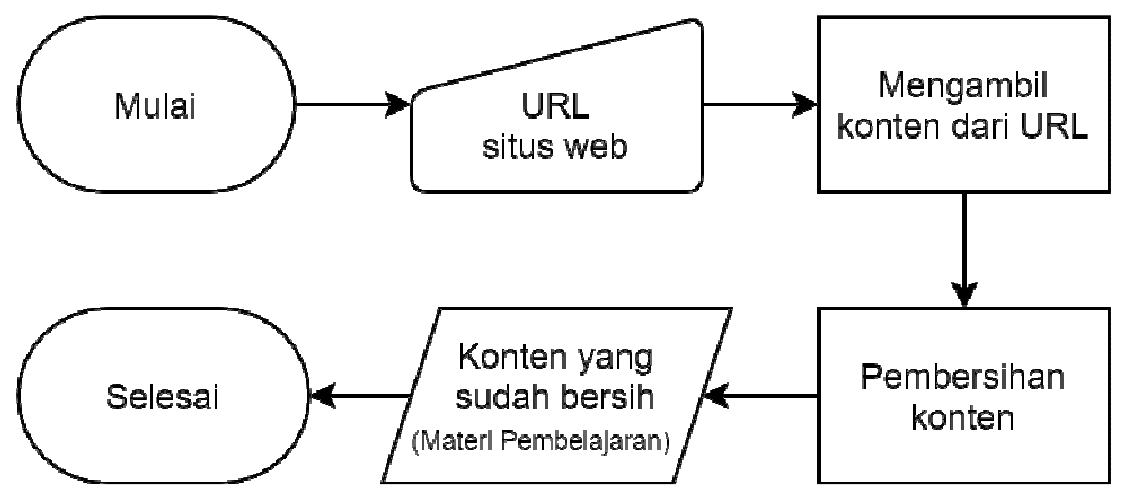

Gambar 2. Tahapan Proses Scraping dan Pembersihan Data

\subsection{Praproses Data}

Teks materi pembelajaran hasil scraping selanjutnya masuk ke tahap praproses data. Praproses data dilakukan agar semua kata memiliki format yang seragam dan lebih mudah untuk diproses pada tahap selanjutnya. Praproses data terdiri dari case folding, penghapusan tanda baca, simbol, dan angka, tokenisasi, stopword removal, dan stemming. Case folding digunakan untuk mengubah semua karakter menjadi huruf kecil (lowercase). Case folding diimplementasikan menggunakan fungsi lower yang tersedia pada Python. Untuk menghapus

Alfiani, et., al [Implementasi Metode Klasifikasi Multilabel Untuk Kategorisasi Materi Pembelajaran Secara] 
tanda baca, simbol, dan angka yang mungkin dapat menjadi noise pada proses klasifikasi digunakan fungsi regex. Selanjutnya dilakukan tokenisasi untuk memotong kalimat menjadi potongan-potongan kata. Kemudian stopword removal digunakan untuk menghapus kata yang maknanya tidak terlalu penting atau tidak berpengaruh besar pada proses klasifikasi. Tokenisasi dan stopword removal diimplementasi dengan menggunakan bantuan pustaka SpaCy. Sementara untuk stemming bahasa Indonesia digunakan pustaka Sastrawi. Stemming digunakan untuk mengurangi ragam kata pada teks materi pembelajaran dengan mengganti kata menjadi kata dasarnya. Contoh praproses data dapat dilihat pada Gambar 3.

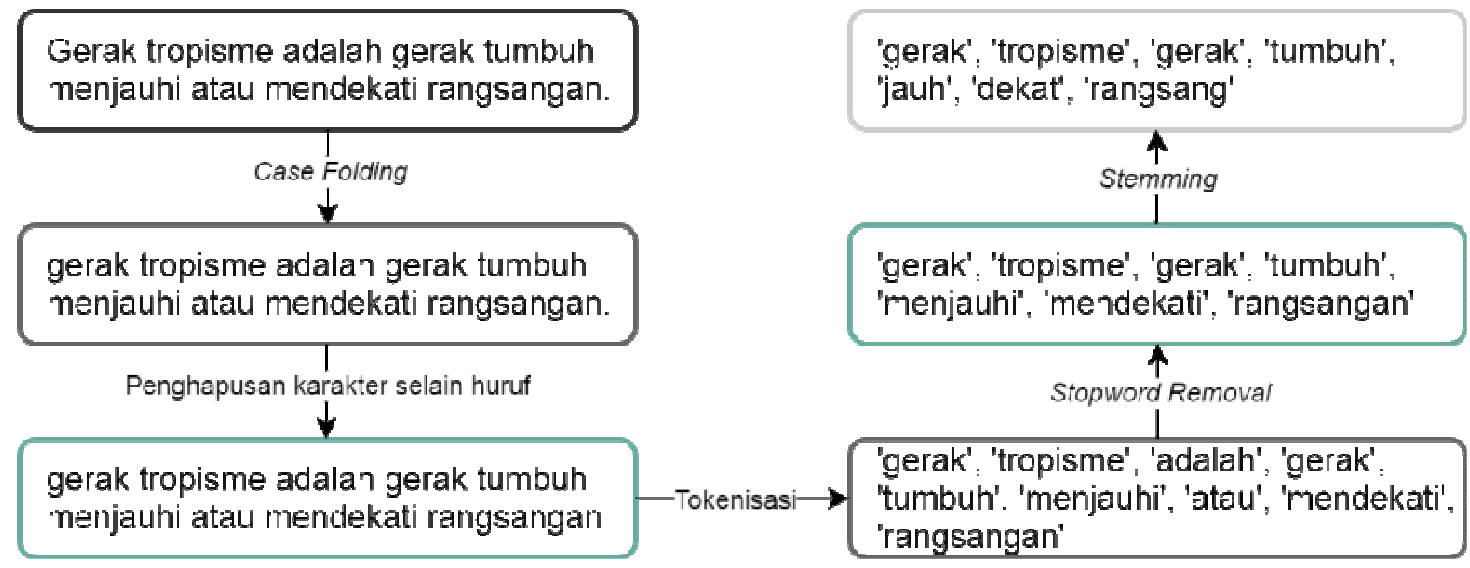

Gambar 3. Contoh Praproses Data

\subsection{Ekstraksi Fitur}

Proses ekstraksi fitur dilakukan engan mencari pembobotan term menggunakan TF-IDF (Term Frequency-Inverse Document Frequency). Pertama, pada sebuah data dihitung jumlah atau frekuensi setiap term-nya. Jika suatu term pada data tersebut sering muncul, maka bobot yang didapatkan akan lebih besar. Lalu term tersebut dihitung juga bobotnya secara invers. Semakin sedikit persebaran term tersebut dari seluruh dataset/dokumen, maka bobotnya semakin besar. Hal ini berarti term tersebut memiliki keunikan tersendiri pada data-data tertentu.

Nilai TF-IDF diperoleh dari perkalian antara TF dan IDF. TF merupakan banyaknya sebuah term yang terdapat pada sebuah dokumen. TF untuk sebuah term pada sebuah dokumen dihitung dengan menggunakan persamaan (1). Sedangkan IDF memberikan bobot yang lebih rendah pada suatu term jika kemunculannya banyak tersebar di seluruh dokumen [7]. IDF untuk sebuah term diperoleh dengan menggunakan persamaan (2) dengan $N$ merupakan jumlah dokumen dan $d f t$ merupakan jumlah dokumen yang menggandung term $\mathrm{t}$.

\subsection{Klasifikasi}

$$
\begin{gathered}
T F_{t A}=\frac{\text { frehuensi termpado dohumen }}{\text { jumlah termpada dohumen }}(1) \\
\qquad I D F_{z}=\log \left(\frac{N}{d f_{i}}\right)(2)
\end{gathered}
$$

Klasifikasi materi pembelajaran dilakukan berdasarkan topik dan subtopik pembelajaran. Proses klasifikasi secara otomatis dilakukan dengan menerapkan metode klasifikasi multilabel. Hal ini dikarenakan materi pembelajaran dapat dikategorisasikan menjadi lebih dari satu topik atau subtopik yang berbeda. 
Masalah klasifikasi multilabel diselesaikan dengan menggunakan pendekatan transformasi masalah [8]. Pendekatan ini mengubah masalah multilabel menjadi satu atau beberapa masalah label tunggal sehingga dapat diselesaikan menggunakan algoritma pembelajaran label tunggal [9]. Misalkan pada penelitian ini data materi pembelajaran dilabeli berdasarkan kategori topik dan subtopiknya seperti ditunjukkan pada Tabel 1. Maka kemudian perlu dilakukan transformasi kolom 'topik' dan 'subtopik' pada Tabel 1 menjadi serangkaian kolom dengan nilai biner seperti ditunjukkan pada Tabel 2. Selanjutnya proses klasifikasi dilakukan dengan mengimplementasikan metode transformasi masalah. Pada penelitian ini metode transformasi masalah yang digunakan adalah Binary Relevance, dilanjutkan dengan klasifikasi menggunakan algoritma SVM.

Tabel 1. Contoh Pelabelan Data Materi Pembelajaran

\begin{tabular}{|c|c|c|}
\hline Materi & Topik & Subtopik \\
\hline Materi 01 & Sistem Pencernaan Manusia & Organ Pencernaan, Proses Pencernaan \\
\hline Materi 02 & Sistem Pencernaan Manusia & Organ Pencernaan \\
\hline Materi 03 & Sistem Pencernaan Manusia & $\begin{array}{c}\text { Organ Pencernaan, Proses Pencernaan, } \\
\text { Gangguan Pencernaan }\end{array}$ \\
\hline Materi 04 & Sistem Pencernaan Manusia & Organ Pencernaan, Proses Pencernaan \\
\hline
\end{tabular}

Tabel 2. Contoh Transformasi Data Materi Pembelajaran

\begin{tabular}{|c|c|c|c|c|}
\hline Materi & $\begin{array}{c}\text { Sistem Pencernaan } \\
\text { Manusia }\end{array}$ & $\begin{array}{c}\text { Organ } \\
\text { Pencernaan }\end{array}$ & $\begin{array}{c}\text { Proses } \\
\text { Pencernaan }\end{array}$ & $\begin{array}{c}\text { Gangguan } \\
\text { Pencernaan }\end{array}$ \\
\hline Materi 01 & 1 & 1 & 1 & 0 \\
\hline Materi 02 & 1 & 1 & 0 & 0 \\
\hline Materi 03 & 1 & 1 & 1 & 1 \\
\hline Materi 04 & 1 & 1 & 1 & 0 \\
\hline
\end{tabular}

Metode Binary Relevance (BR) mengubah dataset multilabel menjadi $n$ dataset single label, dimana $n$ adalah banyaknya label yang ada pada dataset [10]. Selanjutnya, $n$ dataset dengan single label tersebut dilatih menggunakan binary classifier. Setiap sampel baru kemudian diprediksi menggunakan binary classifier tersebut. Setelah diperoleh prediksi dari setiap binary classifier, hasil prediksi tersebut digabungkan sehingga terbentuk hasil prediksi yang berbentuk multilabel. BR merupakan metode yang populer dan paling banyak digunakan, serta memiliki kompleksitas komputasi yang rendah. Namun, BR tidak mempertimbangkan hubungan korelasi antar label dan menangani label secara terpisah [11]. Sebagai contoh, dari data yang ditunjukkan pada Tabel 2 apabila diterapkan metode BR maka menjadi seperti Tabel 3.

Tabel 3. Contoh Implementasi Binary Relevance

\begin{tabular}{|c|c|c|c|}
\hline Materi & $\begin{array}{c}\text { Sistem Pencernaan } \\
\text { Manusia }\end{array}$ & Materi & Organ Manusia \\
\hline Materi 01 & 1 & Materi 01 & 1 \\
\hline Materi 02 & 1 & Materi 02 & 1 \\
\hline Materi 03 & 1 & Materi 03 & 1 \\
\hline Materi 04 & 1 & Materi 04 & 1 \\
\hline
\end{tabular}




\begin{tabular}{|c|c|}
\hline Materi & Proses Pencernaan \\
\hline Materi 01 & 1 \\
\hline Materi 02 & 0 \\
\hline Materi 03 & 1 \\
\hline Materi 04 & 1 \\
\hline
\end{tabular}

\begin{tabular}{|c|c|}
\hline Materi & $\begin{array}{c}\text { Gangguan } \\
\text { Pencernaan }\end{array}$ \\
\hline Materi 01 & 0 \\
\hline Materi 02 & 0 \\
\hline Materi 03 & 1 \\
\hline Materi 04 & 0 \\
\hline
\end{tabular}

\section{HASIL DAN PEMBAHASAN}

Sistem yang dikembangkan pada penelitian ini terdiri dari tiga bagian utama, yaitu: pengambilan data, praproses data, dan kategorisasi otomatis. Bagian pengambilan data berfungsi untuk mengambil konten web dari suatu URL situs web dengan cara scraping. Modul ini sekaligus melakukan proses pembersihan data dari berbagai elemen HTML/CSS/Javascript yang tidak berguna. Bagian praproses data berfungsi untuk menyeragamkan format data agar memudahkan proses berikutnya. Sedangkan bagian kategorisasi otomatis berfungsi melakukan kategorisasi materi pembelajaran secara otomatis berdasarkan topik dan subtopiknya. Proses kategorisasi diawali dengan melakukan ekstraksi fitur terhadap materi pembelajaran, selanjutnya dilakukan klasifikasi multilabel dengan pendekatan transformasi masalah. Tahapan ini memberikan hasil prediksi kategori topik dan subtopik dari teks materi pembelajaran.

Sistem kategorisasi materi pembelajaran secara otomatis berdasarkan topik dan subtopik dibangun dengan menggunakan model klasifikasi yang sudah dilatih sebelumnya. Model ini dibangun menggunakan dataset berupa teks materi pembelajaran Ilmu Pengetahuan Alam (IPA) untuk siswa Sekolah Menengah Pertama (SMP) dengan total data sebanyak 448 materi pembelajaran. Data ini telah dilabeli secara manual, dimana terdiri dari 10 topik dan 41 subtopik. Data materi pembelajaran dapat dikategorikan menjadi lebih dari satu topik atau subtopik. Model klasifikasi diimplementasikan dengan menggunakan metode transformasi masalah Binary Relevance dan algoritma SVM. Dengan menggunakan metode Binary Relevance, model klasifikasi multilabel membangun masing-masing model klasifikasi dari setiap label.

Kinerja model klasifikasi diuji dengan mengukur nilai akurasi, F-Measure, dan hamming loss dari model tersebut. Akurasi dapat dikatakan sebagai proporsi klasifikasi yang benar dari total data. F-Measure merupakan weighted average dari presisi dan recall. Akurasi dan F-Measure mencapai nilai terbaik pada skor 1 dan nilai terburuk pada skor 0. Sedangkan hamming loss adalah banyaknya kesalahan klasifikasi terhadap data yang diuji. Semakin rendah nilai hamming loss, maka semakin baik kinerja dari classifier.

Pengujian dilakukan dengan pembagian dataset menggunakan percentage split berdasarkan rasio data latih dan data uji. Pada penelitian ini digunakan tiga perbandingan rasio data latih dan data uji yaitu: 70:30\%, 75:25\%, dan 80:20\%. Hasil evaluasi untuk model klasifikasi berdasarkan topik dan subtopik terdapat pada Tabel 4. Berdasarkan topiknya, hasil terbaik diraih ketika rasio data latih dan data uji 70:30 dengan akurasi mencapai 0.933, FMeasure sebesar 0.966, dan hamming loss senilai 0.0066. Sedangkan berdasarkan subtopiknya, hasil terbaik diraih ketika rasio data latih dan data uji 75:25 dengan akurasi mencapai 0.696, FMeasure sebesar 0.860, dan hamming loss senilai 0.0089. Evaluasi ini memberikan gambaran bahwa proses klasifikasi materi pembelajaran berdasarkan topik dan subtopiknya dengan menggunakan klasifikasi multilabel sudah memberikan hasil yang cukup baik. 
Tabel 4. Hasil Evaluasi Model Klasifikasi

\begin{tabular}{|c|c|c|c|c|c|c|}
\cline { 2 - 7 } \multicolumn{1}{c|}{} & \multicolumn{3}{c|}{ Topik } & \multicolumn{3}{c|}{ Subtopik } \\
\cline { 2 - 7 } & $\mathbf{7 0 : 3 0}$ & $\mathbf{7 5 : 2 5}$ & $\mathbf{8 0 : 2 0}$ & $\mathbf{7 0 : 3 0}$ & $\mathbf{7 5 : 2 5}$ & $\mathbf{8 0 : 2 0}$ \\
\hline Akurasi & 0.933 & 0.928 & 0.922 & 0.681 & 0.696 & 0.644 \\
\hline F-Measure & 0.966 & 0.963 & 0.960 & 0.848 & 0.860 & 0.836 \\
\hline Hamming Loss & 0.0066 & 0.0071 & 0.0077 & 0.0097 & 0.0089 & 0.0105 \\
\hline
\end{tabular}

Untuk menguji apakah sistem yang dibangun berhasil melakukan klasifikasi otomatis, maka dilakukan pengujian dengan menggunakan 100 URL situs web yang memuat materi pembelajaran. URL situs web di-input-kan ke sistem dan kemudian sistem mengambil konten web yang ada di URL ini. Konten web yang diambil berupa teks materi pembelajaran. Selanjutnya sistem akan memprediksi topik dan subtopik dari materi pembelajaran tersebut. Dari 100 data materi pembelajaran, sistem berhasil memprediksi 98 materi dengan benar sesuai topik aktualnya. Sementara berdasarkan subtopik pembelajaran, terdapat 79 materi yang berhasil diprediksi benar oleh sistem sesuai dengan subtopik aktualnya.

Contoh hasil klasifikasi otomatis dapat dilihat pada Tabel 5 dan Tabel 6. Tabel 5 menunjukkan bahwa materi pembelajaran diprediksi dengan benar berdasarkan topik dan subtopiknya. Sedangkan Tabel 6 menunjukkan bahwa model berhasil memprediksi materi pembelajaran dengan benar berdasarkan topiknya, tetapi subtopiknya masih kurang tepat karena terdapat label yang tidak berhasil diprediksi oleh sistem.

Tabel 5. Contoh Materi Pembelajaran Dengan Prediksi Semua Benar

\begin{tabular}{|c|l|l|}
\hline URL & https://blog.edukasystem.com/sistem-gerak-pada-manusia/ \\
\hline \multirow{5}{*}{$\begin{array}{c}\text { Materi } \\
\text { Pembelajaran }\end{array}$} & $\begin{array}{l}\text { "Dalam kehidupan sehari-hari, kita pasti melakukan aktivitas atau } \\
\text { kegiatan tertentu. Misalnya, berjalan, berenang, berlari, atau bahkan } \\
\text { sekadar bermain game di HP. Dalam melakukan kegiatan tersebut, } \\
\text { anggota tubuh akan bergerak. Ada banyak hal atau unsur yang } \\
\text { membuat tubuh kita aktif bergerak, seperti otot, rangka ataupun sendi } \\
\text { dengan berbagai fungsinya masing-masing. Sistem gerak adalah salah } \\
\text { satu sistem organ yang berfungsi dalam membantu pergerakan tubuh. } \\
\text {..." }\end{array}$ \\
\hline \multirow{2}{*}{ Aktual } & \multicolumn{1}{|c|}{ Topik } & \multicolumn{1}{c|}{ Subtopik } \\
\hline Prediksi & Makhluk Hidup & $\begin{array}{l}\text { Gerak Benda dan } \\
\text { Makhluk Hidup }\end{array}$ \\
\hline
\end{tabular}

Tabel 6. Contoh Materi Pembelajaran Dengan Prediksi Sebagian Benar

\begin{tabular}{|c|l|}
\hline URL & https://fisikazone.com/hukum-pascal-tentang-zat-cair/ \\
\hline & "Hukum Pascal berbunyi: "Apabila tekanan diberikan pada satu \\
& bagian zat cair dalam suatu ruangan tertutup, akan diteruskan oleh \\
Materi & zat cair ke segala arah dengan sama besar". Gejala tekanan pada zat \\
Pembelajaran & Pair ini pertama kali diteliti oleh seorang ahli fisika, yaitu Blaise \\
& Pascal (1623-1662) hingga muncul hukum yang disebut Hukum \\
& dimanfaatkan, terutama dalam bidang otomotif, di antaranya pada \\
& dongkrak hidrolik dan rem piringan hidrolik....." \\
\hline
\end{tabular}




\begin{tabular}{|c|l|l|}
\hline \multicolumn{1}{|c|}{ Topik } & \multicolumn{1}{c|}{ Subtopik } \\
\hline Aktual & Tekanan Zat & $\begin{array}{l}\text { Tekanan Zat Cair, } \\
\text { Aplikasi Konsep Tekanan Zat }\end{array}$ \\
\hline Prediksi & Tekanan Zat & Tekanan Zat Cair \\
\hline
\end{tabular}

\section{KESIMPULAN}

Pada penelitian ini dibangun sebuah sistem yang dapat mengambil materi pembelajaran dari situs web dan mengkategorisasikan materi pembelajaran tersebut secara otomatis berdasarkan topik dan subtopiknya. Proses pengambilan materi pembelajaran dari situs web dengan cara scraping telah berhasil dilakukan. Materi pembelajaran yang berhasil diambil tersebut juga berhasil dikategorisasikan secara otomatis berdasarkan topik dan subtopiknya menggunakan metode klasifikasi multilabel. Dengan penelitian ini dapat disimpulkan bahwa implementasi klasifikasi multilabel dapat digunakan untuk melakukan kategorisasi materi pembelajaran secara otomatis berdasarkan topik dan subtopik pembelajaran.

\section{SARAN}

Berikut beberapa saran untuk pengembangan penelitian lebih lanjut di masa yang akan datang:

1. Mengeksplorasi metode klasifikasi yang digunakan sehingga hasil kategorisasi materi pembelajaran berdasarkan topik dan subtopiknya menjadi lebih akurat. Pada penelitian ini klasifikasi yang digunakan masih sebatas berdasarkan frekuensi kata dalam suatu dataset atau dokumen. Pada penelitian selanjutnya dapat dilakukan dengan mempertimbangkan makna atau kesamaan semantik antar kata.

2. Membangun sebuah sistem yang secara real-time dapat mengumpulkan dan mengkategorisasikan materi pembelajaran yang muncul di internet.

\section{DAFTAR PUSTAKA}

[1] M. Liu, E. McKelroy, S. B. Corliss, and J. Carrigan, 2017, "Investigating The Effect of An Adaptive Learning Intervention On Students' Learning," Educ. Technol. Res. Dev., Vol. 65, No. 6, pp. 1605-1625, doi: 10.1007/s11423-017-9542-1.

[2] B. Forsyth, C. Kimble, J. Birch, G. Deel, and T. Brauer, 2016. "Maximizing The Adaptive Learning Technology Experience,” J. High. Educ. Theory Pract., Vol. 16, No. 4, pp. 8088 ,

[3] A. D. Herlambang and S. H. Wijoyo, 2019, "Algoritma Nä̈ve Bayes untuk Klasifikasi Sumber Belajar Berbasis Teks pada Mata Pelajaran Produktif di SMK Rumpun Teknologi Informasi dan Komunikasi," J. Teknol. Inf. dan Ilmu Komput., Vol. 6, No. 4, pp. 431-436, doi: 10.25126/jtiik.201961323. 
[4] T. Gunarathne, T. Shih, C. Chootong, W. Sommool, and A. Ochirbat, 2020. "An Automated Learning Content Classification Model (LCCM) for Open Education Repositories - Case of MERLOT II,” J. Internet Technol., No. Lccm,

[5] T. B. Lalitha and P. S. Sreeja, 2020, "Personalised Self-Directed Learning Recommendation System,” Procedia Comput. Sci., Vol. 171, 2019, pp. 583-592, doi: 10.1016/j.procs.2020.04.063.

[6] Y. Hillier, 2005, Reflective Teaching in Further and Adult Education: Second Edition. London, UK: A\&C Black,.

[7] S. Qaiser et al., 2018, "Text Mining: Use of TF-IDF to Examine the Relevance of Words to Documents," Artic. Int. J. Comput. Appl., Vol. 181, No. 1, pp. 975-8887, doi: 10.5120/ijca2018917395.

[8] D. Rahmawati and M. L. Khodra, 2015, "Automatic Multilabel Classification for Indonesian News Articles," ICAICTA 2015 - 2015 Int. Conf. Adv. Informatics Concepts, Theory Appl., pp. 1-6, doi: 10.1109/ICAICTA.2015.7335382.

[9] G. Tsoumakas and I. Katakis, 2007, “Multi-Label Classification: An Overview," Int. J. Data Warehous. Min., doi: 10.4018/978-1-60566-058-5.ch021.

[10] P. Prajapati, A. Thakkar, and A. Ganatra, 2012. "A Survey and Current Research Challenges in Multi-Label Classification Methods," Int. J. Soft Comput. Eng. IJSCE, Vol. 2, No. 1, pp. 248-252,

[11] P. ElKafrawy, A. Mausad, and H. Esmail, 2015, "Experimental Comparison of Methods for Multi-Label Classification in Different Application Domains," Int. J. Comput. Appl., Vol. 114, No. 19, pp. 1-9, doi: 10.5120/20083-1666. 